УДК $552.52 ; 552.08 ; 553.611$

\title{
ГЛИНЫ ТАВДИНСКОЙ СВИТЫ ЭОЦЕНА: ЛИТОГЕОХИМИЧЕСКИЕ И СЕДИМЕНТОЛОГИЧЕСКИЕ АСПЕКТЫ (КЫШТЫРЛИНСКОЕ МЕСТОРОЖДЕНИЕ, ЗАПАДНАЯ СИБИРЬ)
}

Смирнов Павел Витальевич ${ }^{1,2}$, geolog.08@mail.ru

Дерягина Оксана Ивановна', deriaginaoksanazsgc@yandex.ru

Новоселов Андрей Андреевич ${ }^{1,2}$ mr.andreygeo@mail.ru

\section{Трубин Ярослав Сергеевич',} iyr-2009@mail.ru

Баталин Георгий Александрович ${ }^{4}$, g@batalin.com

Гареев Булат Ирекович ${ }^{4}$, bulat@gareev.net

Плюснин Алексей Владимирович ${ }^{5}$, geolog0112@mail.ru

1 Тюменский индустриальный университет, Россия, 625000, г. Тюмень, ул. Володарского, 38

2 Тюменский государственный университет, Россия, 625003, г. Тюмень, ул. Володарского, 6.

${ }^{3}$ О०О «Западно-Сибирский геологический центр», Россия, 625002, г. Тюмень, ул. Сургутская, 11, к. 4.

${ }^{4}$ Казанский федеральный университет, Россия, 420008, г. Казань, ул. Кремлевская, 4/5.

5 Пермский государственный национальный исследовательский университет, Россия, 614990, г. Пермь, ул. Букирева, 15.

Актуальность. Минеральный состав глин тавдинской свиты изучался неоднократно. Полученные результаты, содержащиеся в геологических отчетах и немногочисленных опубликованных работах, зачастую слабо коррелируются друг с другом. Подобное противоречие вызвано отбором проб для технологических испытаний с различных участков, которые относятся к двум подсвитам, имеющим ряд отличий. Возраст, стратиграфическое положение и химико-минералогические особенности пород, слагающих тавдинскую свиту, остаются дискуссионными и актуальными вопросами, что требует дополнительных исследований. Детальное изучение литологии глин тавдинской свиты принимает важное значение в связи с планами по расширению сырьевой базы и потребностью перепрофилизации части производственных мощностей на выпуск новой товарной продукции.

Цель работы: изучение вещественного состава глин тавдинской свиты эоцена Западной Сибири для выявления их генезиса и практического использования

Методы: полевые исследования, рентгеноструктурный анализ, рентгенофлуоресцентный анализ, определение огнеупорности, масс-спектрометрия с индуктивно-связанной плазмой, сканирующая электронная микроскопия, литолого-петрографический анализ в шлифах.

Результаты. Представлены результаты исследований химического и минерального составов, особенностей литологии и микростроения глинистых пород из Кыштырлинского участка (Тюменская область). Глинистые породы обладают определенной вариативностью минерального состава, но неизменным остается глинистый слюдистый смешаннослойно-смектитовый матрикс. В нижней подсвите глинистая масса пород сложена преимущественно иллитом и смешанослойными образованиями иллит-смектитового состава. Глины верхней подсвиты больше соответствуют каолинит-иллит-монтмориллонитовому типу с примесями пирита, минералов кремнезёма, сульфатов, карбонатов и органического вещества. Формирование таких смешаннослойных масс, вероятно, обусловлено трансформацией обломочных минералов и первичного глинистого субстрата. Установленное распределение редкоземельных элементов индицирует существенные изменения в восстановительно-окислительных условиях морского бассейна на различных этапах его существования. Изученные глины рассматриваются как полиминеральные.

Ключевые слова:

Глины, глинистые минералы, тавдинская свита, эоцен, неметаллические полезные ископаемые, Западная Сибирь. 


\section{Введение}

Юг Тюменской области располагает значительной минерально-сырьевой базой глинистых пород различных возрастов и генетических типов. На юге региона основными литостратиграфическими объектами на глинистое сырье являются морские отложения тавдинской свиты бартонаприабона (средний и верхний эоцен), а объектами минеральной базы глин являются Богандинский, Головинский и Кыштырлинский участки разведанного в 1966 г. Богандинского месторождения. Все три участка имеют сходный разрез, близко расположены и обладают суммарными запасами по категории $\mathrm{A}+\mathrm{B}+\mathrm{C}_{1} 82,92$ млн м². В 1966 г. на Кыштырлинском участке была начата эксплуатация и организована добыча глины для керамзитового завода. С этого момента месторождение стало сырьевой базой для предприятий юга Тюменской области, специализирующихся на производстве стеновых материалов, керамзитового гравия, блоковых и силикатных изделий.

Минеральный состав глин Кыштырлинского участка определялся неоднократно лабораториями НИИкерамзит (1969 г.), НИИстройкерамики (1971 г.) и ПГО «Уралгеологии» (1989 г.). Однако результаты отличаются довольно существенно и слабо коррелируются между собой: содержание монтмориллонита в глинах колеблется от 19 до $30 \%$, а слюды - от 16 до $45 \%$. По мнению коллектива авторов, это может быть связано как с отбором проб для технологических испытаний с различных участков, так и с общей вариативностью минерального состава этих пород. В период выполнения лабораторных исследований и технологических испытаний (1966-1970-е гг.) отсутствовало понимание, что в пределах Кыштырлинского участка вскрываются две толщи, имеющие ряд отличий в минеральном составе и относящиеся по палеонтологическим данным к верхней и нижней подсвитам тавдинской свиты [1-6]. Возраст, стратиграфическое положение, химико-минералогические особенности глин тавдинской свиты остаются актуальными вопросами и требуют дополнительных исследований.

На протяжении многих лет обсуждаются возможности расширения сферы использования глин тавдинской свиты в отраслях, отличных от индустрии строительных материалов. По мнению ряда ученых $[7,8]$ глины тавдинской свиты могут быть сходны по минеральному составу с бентонитовыми глинами Бикляньского месторождения Татарстана и с глинами Зырянского месторождения Курганской области $[9,10]$, используемыми во многих производствах и особо широко - для приготовления глинопорошка для буровых растворов. Детальное изучение литологии глин тавдинской свиты имеет важное значение в связи с планами по расширению сырьевой базы и потребностью перепрофилизации части производственных мощностей на выпуск новой товарной продукции. Однородность сырья рассматривается как непременное условие для обеспечения заданных свойств товарной продукции и как фактор снижения технологических рисков.

\section{Объекты и методы исследования}

Отложения тавдинской свиты $\left(\mathrm{P}_{2} \mathrm{tv}\right)$ повсеместно распространены на территории Западной Сибири и формируют значительный объем кайнозойских отложений в пределах Западно-Сибирской низменности, в Зауралье и в северной части Тургайского прогиба. Формирование ее осадков было связано с последним этапом существования морского режима в истории Западно-Сибирского бассейна, когда еще поддерживалась устойчивая связь с северной частью Кавказско-Копетдагского моря через Тургайский пролив [11-13].

Физико-географические условия. Кыштырлинский участок (=Кыштырлинское месторождение) керамзитовых глин расположен в 4 км к юго-востоку от пос. Винзили, в 2 км к северо-востоку от д. Кыштырла, в 5 км к северо-западу от железнодорожной станции Богандинская и в 23 км к югу от г. Тюмени (рис. 1).

Орографически район месторождения представляет собой всхолмленную равнину с абсолютными отметками 55-65 м. Геоморфологически площадь приурочена к первой и частично (северо-восточная часть) ко второй надпойменным террасам p. Пышмы. Месторождение пересекается в северной части небольшой рекой Кыштырлой, которая питается грунтовыми водами. В настоящее время воды р. Кыштырла несточные, т. к. в районе железной дороги русло реки перекрыто насыпью. Вскрытая выработками мощность глин на месторождении составляет $19 \mathrm{~m}$, зафиксированная при разведочном бурении мощность полезной толщи порядка 60-80 м.

Лабораторные исследования. Для проведения лабораторных и микроскопических исследований отобраны две валовые пробы с западного и восточного бортов Кыштырлинского карьера общей массой 120 кг. Полуколичественное определение минерального состава проводилось рентгеноструктурным методом в 000 «Западно-Сибирский геологический центр» (г. Тюмень) на рентгеновском дифрактометре ДРОН-4 с дальнейшей обработкой дифрактограмм на программной платформе $\mathrm{Ge}$ oQuant, с помощью которого удалялись ошибки автоматического распознавания и паразитные пики.

Определение содержания полуторных оксидов проводилось на рентгенофлуоресцентном волнодисперсионном спектрометре S8Tiger (Bruker, Германия) в Лаборатории изотопного и элементного анализа Института геологии и нефтегазовых технологий Казанского Федерального университета (г. Казань), который позволяет определять элементный состав твердых, порошкообразных и жидких образцов в диапазоне от В до U в вакууме или в атмосфере гелия. Прибор оснащен родиевой рентгеновской трубкой мощностью 4 кВт. Полученная таблетка помещалась в спектрометр, где 
проходил анализ стандартизированной методикой Geoquant. Полученный спектр обрабатывался методом фундаментальных параметров, удалялись ошибки автоматического распознавания, паразитные пики, учитывались дифракционные явления и матричные эффекты, для учета неопределяемых элементов использовалась величина ППП. Исследования элементного состава образцов проводились на масс-спектрометре с индуктивно связанной плазмой iCAPQс (ThermoFisherScientific, Германия). Навеска исследуемого образца массой 100 мг взвешивалась в тефлоновом автоклаве на аналитических весах с точностью 0,1 мг. Полученный раствор анализировался на масс-спектрометре, предварительно откалиброванном с помощью мультиэлементных стандартов с концентрацией в диапазоне от 1 до 100 ppb каждого элемента. Конечные значения концентраций пересчитывались на исходную концентрацию с учетом пустого образца, навески и разбавления раствора. Результаты определения элементного состава представлены в виде диаграммы. При расчете кларков рассеяния и концентрации значения элементов нормализованы к данным K.H. Wedepohl [14].

Литолого-петрографическое описание проводилось в шлифах, подготовленных по стандартной методике. Номенклатура глинистых минералов дается в соответствии с последними рекомендациями по номенклатуре глинистых минералов [15]. Для более детального изучения минерального состава образцов глин, отобранных в пределах Кыштырлинского карьера, был определён их гранулометрический состав. Полученные фракции с размером зёрен 0,1-0,4 мм, 0,01-0,1 мм и менее 0,01 мм просматривались под поляризационным микроскопом. Электронная микроскопия отдельных образцов проводилась на аппаратно-программном комплексе на базе растрового электронного микроскопа JEOL JSM 6510A. Пространственное разрешение до 2,5 нм, ускоряющее напряжение до 20 кВ, ток при спектральном анализе - 1 нА.

Степень засоренности сырья месторождения крупнозернистыми включениями определялась путём промывки глин на сите с диаметром отверстий в свету 0,5 мм с последующим рассевом остатка на сите с диаметром отверстий 2 и 3 мм. Определение огнеупорности выполнено согласно ГОСТ 4069-48 в лаборатории 000 «Тюменьнеруд».

\section{Результаты}

\section{Строение разреза}

Лабораторным исследованиям предшествовали полевые работы в пределах эксплуатируемой и старой, частично затопленной, частей месторождения.

В стенках карьера на дневную поверхность выходят глинистые породы тавдинской свиты эоцена, которые со стратиграфическим несогласием перекрываются четвертичными глинисто-песчаными отложениями (рис. 1).
Нижнетавдинская подсвита представлена глинами темно-серого цвета, участками алевритистыми, пластинчатыми, массивными, с единичным горизонтом, содержащим конкреции, в верхней части разреза. В составе толщи наблюдаются отдельные коричневато-серые конкреции сидерита размерами до 15 см и крупные обломки опок светло-серого цвета.

Практически все органические остатки - двустворки, гастроподы, зубы акул, кости рыб, углефицированная древесина - приурочены к «конкреционным» горизонтам. Видимая мощность нижнетавдинской подсвиты, изученной в карьере, составляет 5 м.

Верхнетавдинская подсвита представлена глинами голубовато-серого и зеленовато-серого цвета, алевритистыми (в отдельных прослоях с мелкими чешуйками слюды), оскольчатыми, участками с тонкой плитчатой отдельностью. В пределах изученных участков отчётливо прослеживаются четыре горизонта, обогащенных конкрециями, в верхней части разреза со стяжениями пирита и кристаллами гипса, с присыпками и мелкими линзами алеврита. Конкреции сидеритового состава коричневато-серого и темно-коричневого цвета, от умеренно до интенсивно биотурбированных, плотные, видимой мощностью до 0,30 м. Как и в случае с нижней подсвитой, органические остатки гастроподы, двустворки, кости рыб, зубы акул и углефицированная древесина - приурочены к «конкреционным» горизонтам. Вскрытая мощность верхнетавдинской подсвиты составляет 8 м.

Контакт нижней и верхней подсвит выражен в смене цвета породы, текстуры и литологического состава.

\section{Физико-технические свойства}

Содержание крупных включений во всех образцах глин незначительное - от 0,1 до $5 \%$, по ГОСТ 9169-59 сырьё классифицируется как со средним содержанием включений и со средними их размерами. По характеру преобладающих включений глины относятся к группе сырья с кварцево-железистыми включениями. Крупные сидеритовые включения распространены в глинах спорадически (по ориентировочным подсчётам содержание конкреций равно 1-2 \% по весу), с глубиной, в нижней подсвите, их содержание значительно уменьшается. В лаборатории 000 «Тюменьнеруд» определена величина огнеупорности, которая составляет $1360-1380{ }^{\circ} \mathrm{C}$. Коэффициент вспучивания изменяется от 2,3 до 9 .

\section{Химико-минералогические особенности}

По химическому составу глины относятся к группе полукислого глинистого сырья, так как содержание $\mathrm{Al}_{2} \mathrm{O}_{3}+\mathrm{TiO}_{2}$ в отдельных пробах достигает $25 \%$. Содержание в глинах $\mathrm{SiO}_{2}$ колеблется в пределах 48-49\%; $\mathrm{Fe}_{2} \mathrm{O}_{3}$ - от 9 до $11 \%$; $\mathrm{CaO}+\mathrm{MgO}$ - от 2 до $4 \%$; п.п.п. - от 7 до $10 \%$ (таблица). 


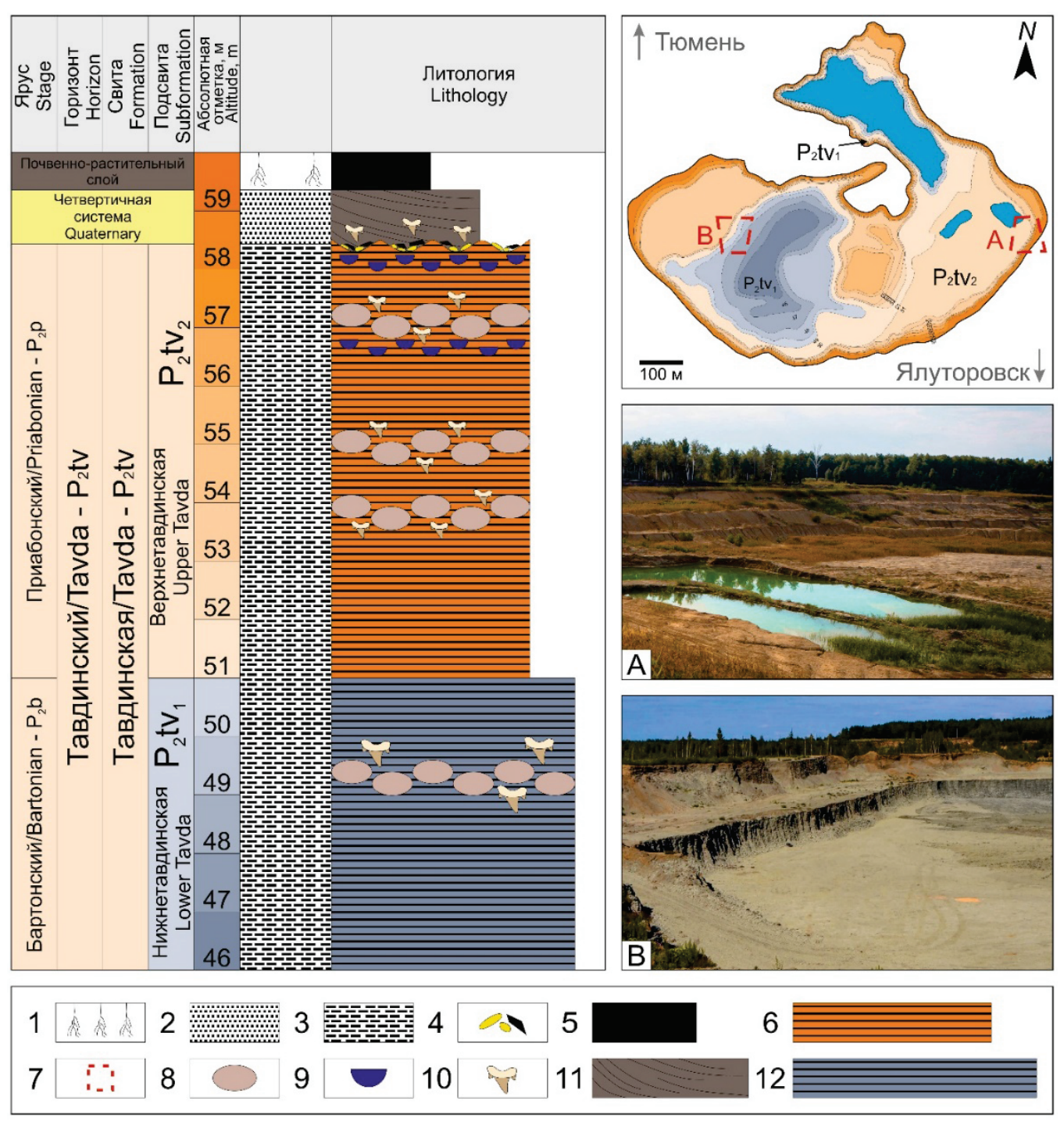

Рис. 1. Схема и седиментологическая колонка Кыштырлинского карьера: 1 - остатки растений; 2 - пески, песчаники, песчанистые отложения; 3 - глины; 4 - аллювиальнал галька; 5 - почвенно-растительный слой; 6 - верхнетавдинскал подсвита; 7 - места отбора валовых проб: $A$ - вехнетавдинская подсвита; $B$ - нижнетавдинская подсвита; 8 - глинисто-кремнистые и сидеритовые конкреции; 9 - кристаллы гипса; 10 - находки ископаемой эоценовой фауны; 11 - пески косослоистые; 12 - нижнетавдинская подсвита

Fig. 1. Scheme and sedimentological column of the Kyshtyrly quarry: 1 are the plant residues; 2 are the sands, sandstones, sandy deposits; 3 is the clay; 4 are the alluvial pebbles; 5 is the top soil layer; 6 is the Upper Tavda subformation; 7 are the gross sampling sites: A - Upper Tavda subformation; $B$ - Lower Tavda subformation; 8 are the clay-siliceous and siderite nodules; 9 are the gypsum crystals; 10 are the finds of fossil Eocene fauna; 11 are the cross-bedded sands; 12 is the Lower Tavda subformation

Существенных флуктуаций в содержании редких и редкоземельных элементов между нижней и верхней подсвитами не наблюдается; исключение составляют Мо и $\mathrm{Sb}$, количество которых отличается на порядок (рис. 2). Еu и Tb образуют мощные аномалии: кларки имеют численные значения в пределах 10.

\section{Литолого-петрографические особенности}

Результаты рентгеноструктурного анализа позволяют фиксировать ряд отличий в минеральном составе пород подсвит (рис. 3). В нижней подсвите глинистая масса пород сложена смешанослойными минеральными образованиями иллит-смекти- тового состава, в котором преобладает монтмориллонит. Последний выявляется по рефлексам со значениями 14,0-15,3 А̊. Присутствуют рефлексы от минералов аморфного кремнезёма в виде гало в области 5,9-3,7 А, рефлекс 4,04 А̊ соответствует кристобалиту. Это свидетельствует о содержании в породе кремнезёма биогенного происхождения, что также было подтверждено микроскопическими исследованиями. Каолинит и хлорит присутствуют в пробах в разных количествах и выделяются по рефлексам 7,1 и $14,1 \AA$.

Глины верхней подсвиты сложены монтмориллонитом, содержание которого варьируется в диапазоне от 23 до $47 \%$. На дифрактограммах фик- 


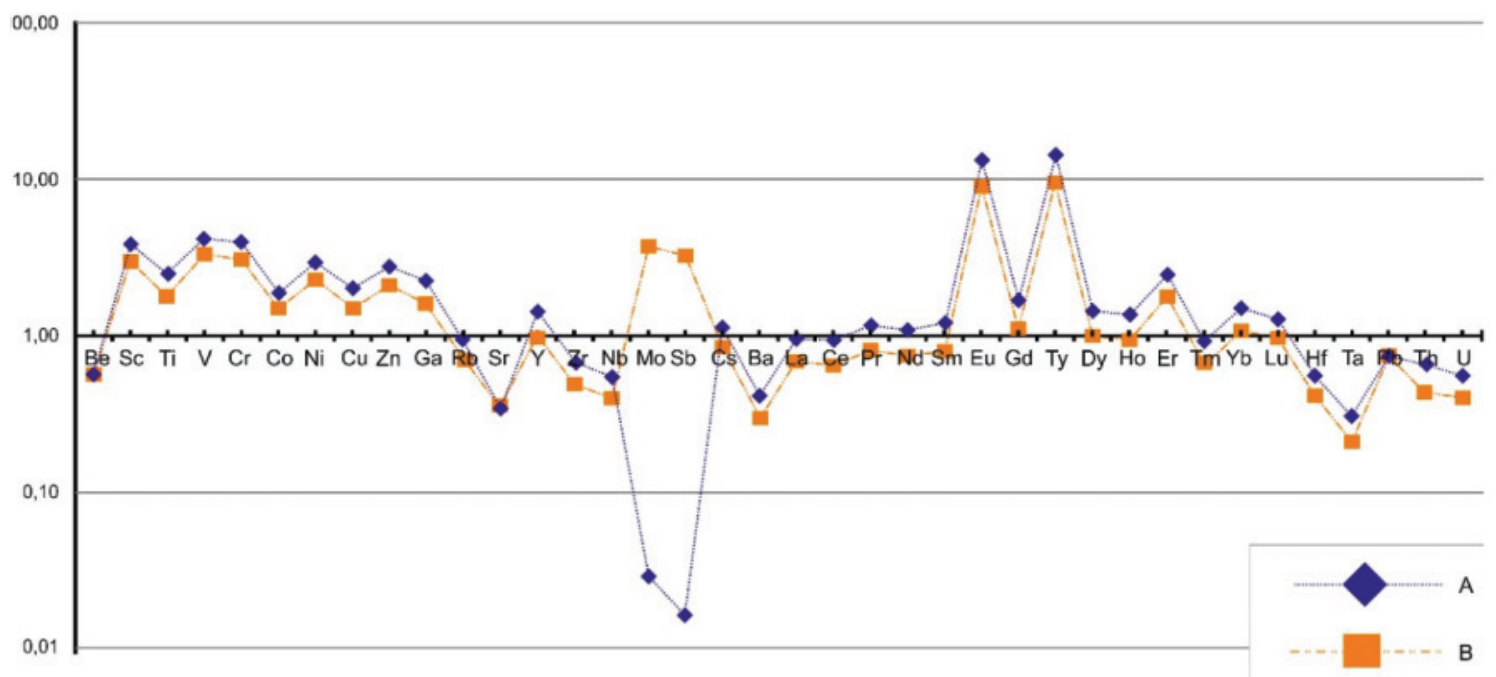

Pис. 2. Редкие и редкоземельные элементы, нормированные на континентальную кору [13]: а) нижняя подсвита; b) верхняя подсвита

Fig. 2. Trace and REE elements normalized to continental crust [13]: a) lower subformation; b) upper subformation
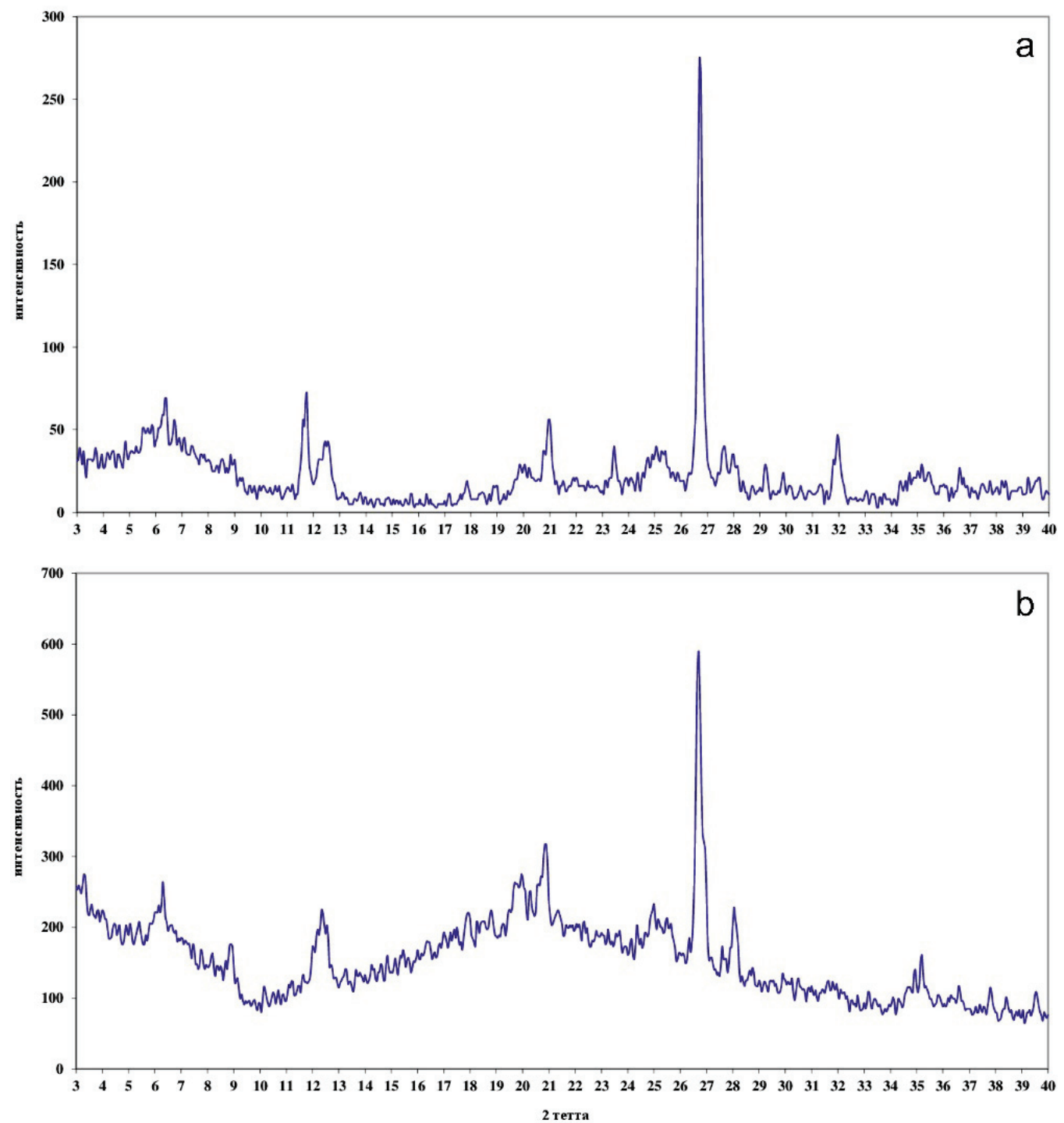

Pис. 3. Представительные дифрактограммы глинистых пород: а) верхнетавдинская подсвита; b) нижнетавдинская подсвита

Fig. 3. Representative diffractograms of clay rocks: a) upper Tavda subformation; b) lower Tavda subformation 
таблица. Усредненные результаты хилического состава, \% Table. $\quad$ Average results of the chemical composition, $\%$

\begin{tabular}{|c|c|c|c|c|c|}
\hline \multirow{2}{*}{$\begin{array}{l}\text { Компонент } \\
\text { Component }\end{array}$} & \multicolumn{5}{|c|}{ Подсвита/Subformation } \\
\hline & $\begin{array}{c}\text { Нижняя } \\
\text { Lower }\end{array}$ & $\begin{array}{c}\text { Верхняя } \\
\text { Upper }\end{array}$ & $\begin{array}{l}\text { Компонент } \\
\text { Component }\end{array}$ & $\begin{array}{c}\text { Нижняя } \\
\text { Lower }\end{array}$ & $\begin{array}{c}\text { Верхняя } \\
\text { Upper }\end{array}$ \\
\hline $\begin{array}{l}\text { п.п.п. } \\
\text { L.0.І. }\end{array}$ & 10,57 & 10,38 & & & \\
\hline $\mathrm{SiO}_{2}$ & 48,37 & 49,29 & $\mathrm{Si}$ & 22,61 & 23,04 \\
\hline $\mathrm{Al}_{2} \mathrm{O}_{3}$ & 23,75 & 22,14 & $\mathrm{Al}$ & 12,57 & 11,72 \\
\hline $\mathrm{Fe}_{2} \mathrm{O}_{3}$ & 8,55 & 8,23 & $\mathrm{Fe}$ & 5,98 & 5,75 \\
\hline $\mathrm{K}_{2} \mathrm{O}$ & 2,65 & 2,52 & $\mathrm{~K}$ & 2,20 & 2,09 \\
\hline $\mathrm{MgO}$ & 2,42 & 2,32 & $\mathrm{Mg}$ & 1,46 & 1,40 \\
\hline $\mathrm{TiO}_{2}$ & 1,08 & 1,13 & $\mathrm{Ti}$ & 0,0648 & 0,675 \\
\hline $\mathrm{CaO}$ & 0,980 & 0,713 & $\mathrm{Ca}$ & 0,700 & 0,509 \\
\hline $\mathrm{Na}_{2} \mathrm{O}$ & 0,560 & 0,498 & $\mathrm{Na}$ & 0,415 & 0,369 \\
\hline $\mathrm{S}$ & 0,524 & $<\Pi 0$ & $\mathrm{Mn}$ & 0,0752 & 0,0648 \\
\hline $\mathrm{P}_{2} \mathrm{O}_{5}$ & 0,104 & 0,0911 & $\mathrm{Ba}$ & 0,0451 & 0,0553 \\
\hline $\mathrm{MnO}$ & 0,0972 & 0,0837 & $\operatorname{Re}$ & 0,0376 & 0,0373 \\
\hline $\mathrm{BaO}$ & 0,0503 & 0,0618 & $\mathrm{~V}$ & 0,0234 & 0,0197 \\
\hline $\mathrm{Re}_{2} \mathrm{O} 7$ & 0,0488 & 0,0485 & $\mathrm{Zr}$ & 0,0228 & 0,0245 \\
\hline $\mathrm{V}_{2} \mathrm{O}_{5}$ & 0,0416 & 0,0353 & $\mathrm{Cl}$ & 0,0283 & $<\Pi 0$ \\
\hline $\mathrm{ZrO2}$ & 0,0308 & 0,0331 & $\mathrm{Sm}$ & 0,0166 & 0,0145 \\
\hline $\mathrm{Cl}$ & 0,0283 & $<\Pi 0$ & $\mathrm{Cr}$ & 0,0129 & 0,0133 \\
\hline $\mathrm{Sm}_{2} \mathrm{O}_{3}$ & 0,0193 & 0,0168 & $\mathrm{~Tb}$ & 0,0133 & 0,0163 \\
\hline $\mathrm{Cr}_{2} \mathrm{O}_{3}$ & 0,0189 & 0,0194 & $\mathrm{Sr}$ & 0,0104 & 0,0105 \\
\hline $\mathrm{Tb}_{4} \mathrm{O}_{7}$ & 0,0156 & 0,0192 & Co & 0,0088 & 0,0090 \\
\hline $\mathrm{SrO}$ & 0,0123 & 0,0168 & $\mathrm{Rb}$ & 0,0105 & 0,0096 \\
\hline $\mathrm{Co}_{3} \mathrm{O}_{4}$ & 0,0120 & 0,0123 & $\mathrm{La}$ & 0,0091 & $<\Pi 0$ \\
\hline $\mathrm{Rb}_{2} \mathrm{O}$ & 0,0155 & 0,0107 & $\mathrm{Ni}$ & 0,0078 & 0,0070 \\
\hline $\mathrm{La}_{2} \mathrm{O}_{3}$ & 0,0107 & $<\Pi 0$ & $\mathrm{Bi}$ & 0,0092 & $<\Pi 0$ \\
\hline $\mathrm{NiO}$ & 0,0099 & 0,090 & $\mathrm{Ge}$ & 0,0057 & 0,0069 \\
\hline $\mathrm{Bi}_{2} \mathrm{O}_{3}$ & 0,0092 & $<\Pi 0$ & $\mathrm{Gd}$ & 0,0069 & $<\Pi 0$ \\
\hline $\mathrm{GeO}_{2}$ & 0,0082 & 0,100 & $\mathrm{Y}$ & 0,0030 & 0,0039 \\
\hline $\mathrm{Gd}_{2} \mathrm{O}_{3}$ & 0,0080 & $<\Pi 0$ & $\mathrm{Hg}$ & $<\Pi 0$ & 0,0107 \\
\hline $\mathrm{Y}_{2} \mathrm{O}_{3}$ & 0,0039 & 0,0050 & & & \\
\hline $\mathrm{HgO}$ & $<\Pi 0$ & 0,0116 & & & \\
\hline
\end{tabular}

сируется по интенсивным пикам со значениями $d_{(001)}=13,8-13,9 ; 14,9-15,1 \AA$ для сухих образцов и $17,5-18,4$ Ал для образцов, насыщенных глицерином. Диффузность и асимметричность рефлексов в малоугловой части дифрактограммы свидетель- ствуют о присутствии в породе смешаннослойного минерального образования иллит-смектитового состава. Гидрослюда выделяется по рефлексам 9,9-10 А̊. Во всех пробах было отмечено присутствие: каолинита по пикам со значениями 7,1 и $3,58 \AA$, гипса - 7,56 А̊, сидерита - 2,8 А.

Соотношения содержания кварца, полевых шпатов и глинистой части пород отображены на треугольной диаграмме (рис. 4). На долю собственно глинистой составляющей приходится 60-70\% от объёма породы. При микроскопическом исследовании пород нижней подсвиты были выделены наиболее характерные для них микротекстуры. Ярко выражена микролинзовидная текстура, сформировавшаяся за счёт скопления зёрен полевошпатокварцевого состава, крупной и мелкоалевритовой размерности с незначительной примесью глинистого материала (рис. 5, a). В породе присутствуют многочисленные ходы илоедов, заполненные терригенным материалом мелкоалевритовой размерности (рис. $5, b)$. Ходы изогнутые с выдержанной шириной от 0,08 до 0,12 мм, беспорядочно ориентированные. Структура пород алевропелитовая, содержание частиц размером 0,01-0,1 мм колеблется в пределах от $24,8-31,4 \%$.

Основная глинистая масса пород нижней подсвиты имеет чешуйчатое строение, сложена преимущественно чешуйками слюды и смешанослойными образованиями иллит-смектитового состава. Под микроскопом с анализатором наблюдается ориентированная текстура микроагрегатов, расположенных параллельно друг другу и поверхностям наслоения, выражается в одновременном погасании оптически ориентированных частиц, обладающих интенсивной жёлто-оранжевой интерференционной окраской (рис. $5, b)$. Также содержится примесь каолинита и хлорита. Каолинит и хлорит в большей степени приурочены к линзам крупно-мелкозернистых алевролитов. Акцессорные минералы представлены эпидотом, клиноцоизитом, турмалином и пироксеном. Органические остатки двух видов. Первые представлены углефи-
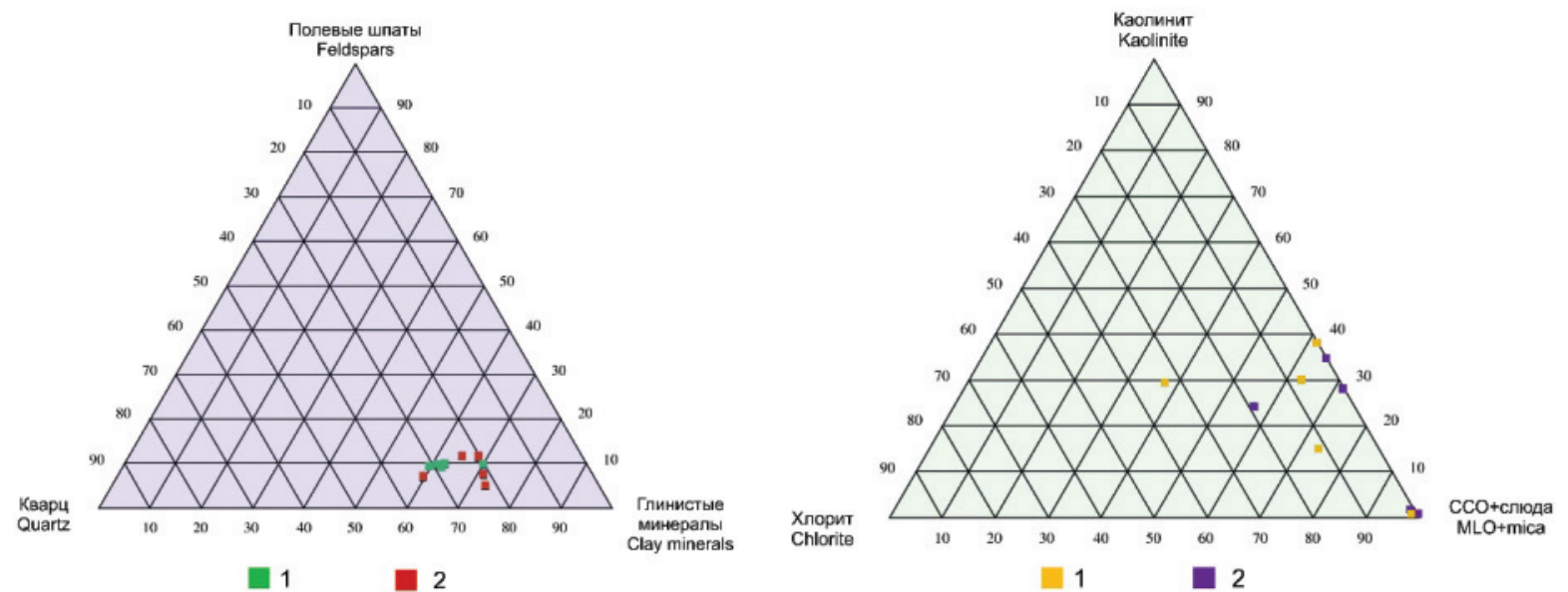

Рис. 4. Диаграмлы минерального состава глинистых пород: 1 - нижнетавдинская подсвита; 2 - верхнетавдинская подсвита

Fig. 4. Diagrams of mineral composition of the clay rocks: 1 - Lower Tavda subformation; 2 - Upper Tavda subformation 

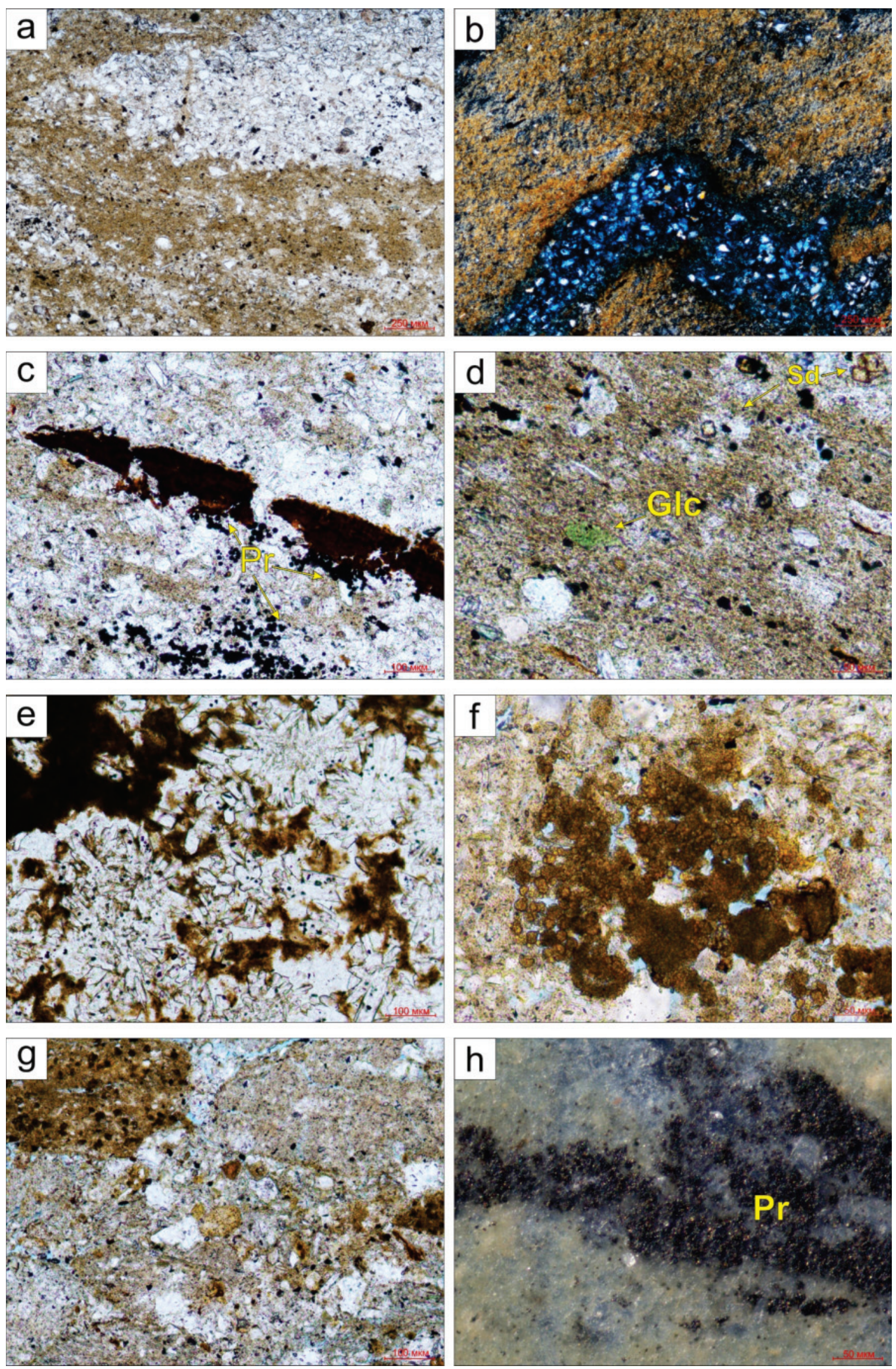
цированными /фюзенизированными обломками детрита (рис. 5, c). Другой вид органических остатков - это обломки и целые панцири диатомовых водорослей, спикулы губок хорошей сохранности. Были отмечены единичные зёрна глауконита зелёного цвета с чёткими контурами зёрен, овальной формы, с микроагрегатным строением, которое наблюдается под микроскопом в скрещенных николях (рис. $5, d)$. Характерно содержание пирита и сидерита в образцах нижней подсвиты. Пирит образует скопления, состоящие из мелких кристалликов, а также агрегатов кристаллитов - фрамбоидов (рис. 5, c). Сидерит присутствует в виде мелких, рассеянных по всей породе кристаллов ромбоэдрического облика с закруглёнными гранями, с желтоватым оттенком, с тонкими каёмками рыже-коричневого цвета за счёт оксидов железа (рис. 5, d), а также в виде пелитоморфной массы. Сидерита не более 1-2 \% от объёма породы.

Для пород верхней подсвиты характерны пятнистая и микролинзовидная текстуры. Пятнистая микротекстура проявляется в неравномерной пигментации глинистой массы оксидами железа и выделяется по цвету (рис. $5, g)$. Пятнистость глинистым породам также придают выделения коричневато-рыжего пелитоморфного сидерита (рис. 5, f). Агрегаты гипса часто сосредоточены в разноразмерных линзовидных образованиях. В удлинённых кристаллах гипса, слагающих агрегаты, очень часто наблюдаются вкрапления тонкодисперсного пирита (рис. 5, e). Основная глинистая масса в образцах верхней подсвиты довольно однородная, имеет полиминеральный состав и тонкочешуйчатое строение. Глина сложена чешуйками размером от 0,005 мм и менее, которые составляют 60-73 \% от общего объёма породы. Под микроскопом с анализатором глинистые частицы проявляют беспорядочную ориентировку, обладают ярко-жёлтыми (иллит-монтмориллонит) и серыми (каолинит) интерференционными окрасками.

Обломочный материал концентрируются преимущественно во фракции 0,01-0,1 мм, его от 27 до $40 \%$. Для него характерно довольно неравномерное послойное распределение, в результате чего может наблюдаться микрослоистое строение в отдельных фрагментах породы. Представлен угловатыми, полуокатанными, изометричными и удли- нёнными зёрнами кварца, полевыми шпатами размером от менее 0,005 до 0,2 мм. Зёрна кварца имеют нормальное погасание, со следами растворения и пылеватыми включениями. На отдельных обломках кварца наблюдаются очень тонкие, прерывистые регенерационные каёмки толщиной 0,01-0,015 мм. Из полевых шпатов отмечены кислый плагиоклаз и микроклин. Слюды с размером чешуек 0,03-0,05 мм немного - 1-2 \% от общего объёма породы. Среди них определены мусковит и биотит, а также их гидратированные разности. При микроскопическом изучении было установлено, что максимальное количество зёрен рудных минералов сконцентрировано во фракции с размером зёрен 0,01-0,001 мм. Рудные минералы представлены пиритом, магнетитом, гематитом. Тонкорассеянный пирит в глинистых породах образует 300- и фитоморфозы (рис. $5, h$ ). Во фракциях 0,1-0,4 и 0,01-0,1 мм обнаружены спикулы губок, панцири диатомовых водорослей. Во всех изученных фракциях были выявлены акцессорные минералы, такие как: эпидот, клиноцоизит, циркон.

\section{Микроскопические морфологические особенности}

В образцах нижней подсвиты изученное поле сложено чешуйками и агрегатами слюды, местами смятыми в складки. Смешаннослойные иллитмонтмориллонитовые агрегаты формируют сплошные массы (рис. 6). Другие минералы (кварц, полевые шпаты и др.) диагностируются слабо, так как их зерна почти всегда в той или иной степени покрыты хлопьями глинистых минералов. Каолинит чаще представлен короткими, так называемыми вермикулярными ("vermicular») [16], агрегатами длиной 5-10 мкм с расщепленными эродированными гранями (рис. $6, d)$.

Верхняя подсвита. Исследуемое поле практически полностью сложено чешуйками, пластинками и натечными образованиями глинистых минералов (рис. $7, a)$, непременным компонентом которых является смектит [17, 18]. Несимметричные хлопьевидные агрегаты смектита нередко ассоциированы с тонкими кристаллитами иллита. В общей массе диагностируются зерна слюд (рис. 7, b), полевых шпатов, кварца и др. минералов. Гипсы встречаются как в виде монокристаллов, так и в

Pис.5. Текстурно-структурные особенности глин по данныл литолого-петрографического анализа в шлифах: а-с) нижнетавдинская подсвита: a) микролинзовидная текстура; $b$ ) одинаковая оптическая ориентировка глинистых частии в основной массе; ходы илоедов, заполненные терригенныл материалом мелкоалевритовой размерности; с) органогенный детрит и скопления фрамбоидального пирита; d) мелкие зерна сидерита ромбического облика с округленныли гранял и зерно глауконита насыщенного зеленого ивета; $e^{-h}$ ) верхнетавдинская подсвита: $е$ ) агрегаты гипса в линзах и прослоях малой толщины; f) сидерит; g) неоднородная структура глин, пятнистая микротекстура; $h$ ) тонкорассеянный пирит в виде фитолорфоз (отраженный свет ). $\mathrm{Pr}$ - пирит; Glc- глауконит; Sd-cидерит

Fig. 5. Textural and structural features of clays according to lithologic-petrographic analysis in thin sections: a-c) lower Tavda subformation clays: a) microlens-like texture; b) identic clay particles optical orientation in the bulk; moves of worms, filled with small-aleuritic terrigenous material; $c$ ) organic residues and aggregation of framboidal pyrite; $d$ ) fine grains of siderite of a rhombic appearance with rounded edges and a grain of green glauconite; $e-h)$ upper Tavda subformation clays: $e$ ) star-shaped aggregates of gypsum in lenses and small thickness interlayers; $f$ ) siderite; $g$ ) heterogeneous structure of clays; $h$ ) fine pyrite, probably developed by organic matter (reflected light) 

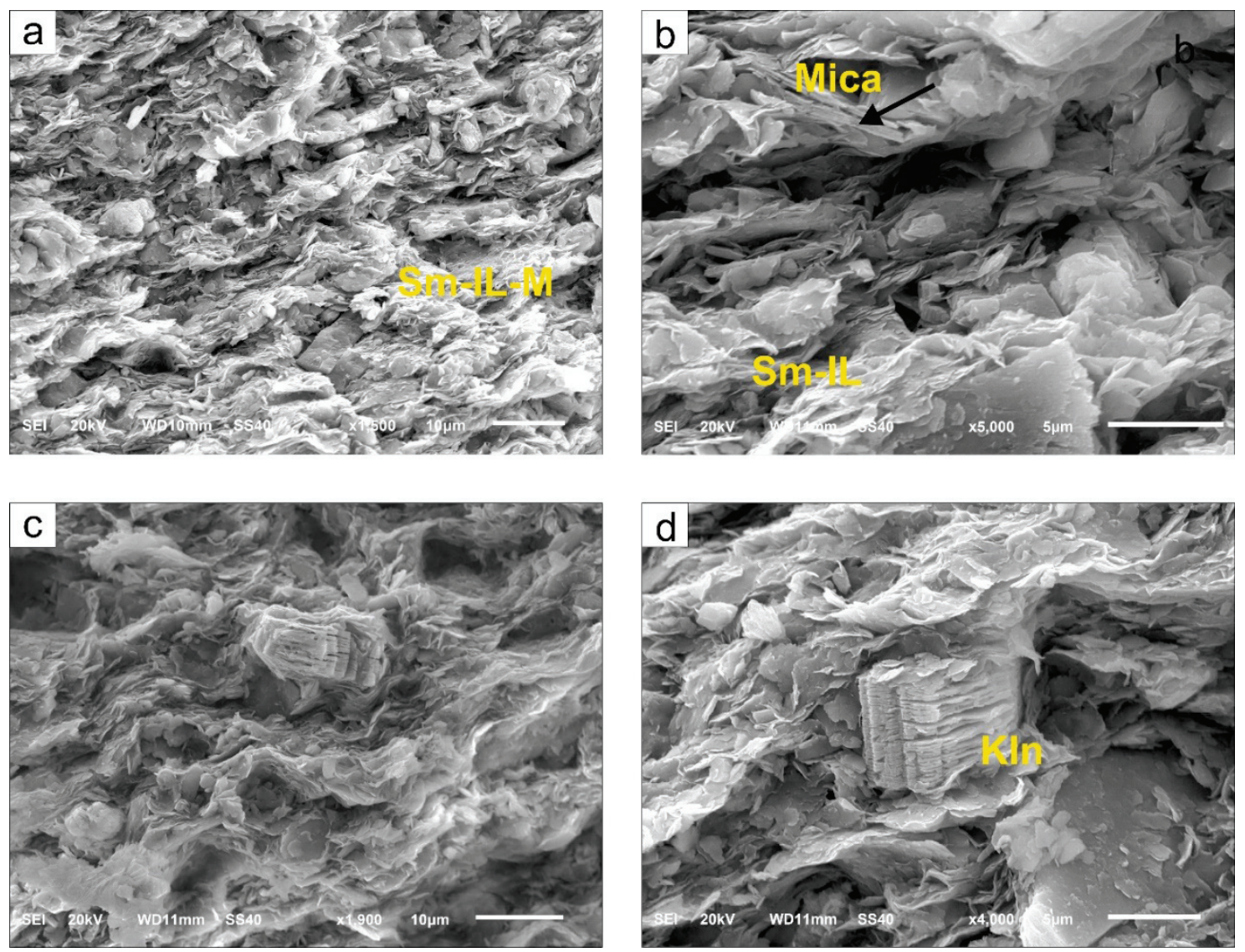

Pис. 6. Микроструктура и минеральные компоненты глин нижнетавдинской подсвиты: а, b) слектит-иллитовые агрегаты с включенияли слюды; c, d) «vеrтісиаг» каолиниты с сильно әродированныли граняли. Sm-IL-M - слюда-смектит-иллит; Sm-IL слектит-иллит; Міса - слюда; Kln - каолинит

Fig. 6. Microstructure and mineral components of lower Tavda subformation clays: a,b) smectite-illite aggregates with inclusions of mica; $c$, d) «vermicular» kaolinites with strongly eroded edges. Sm-IL-M - mica-smectite-illite; Sm-IL - smectite-illite; Mica - mica; Kln - kaolinite

форме двойниковых и тройниковых срастаний, где соединяются уплощенные кристаллы с эродированными гранями (рис. $7, c, d)$. Размер обыкновенно составляет несколько сотен мкм.

\section{Обсуждение и выводы}

Глинистые породы обладают определенной вариативностью минерального состава: точки даже для одной и той же подсвиты на треугольной диаграмме состава глинистой компоненты нередко существенно отстоят друг от друга. Неизменным остается глинистый смешаннослойный иллит-смектитовый матрикс.

Седиментологическая модель глин тавдинской свиты, вероятно, была близка к тем, что имеют место при формировании глин в условиях теплого климата $[10,19]$. В таких условиях размываемая кора выветривания давала обилие тонкого глинистого материала и коллоидных растворов, а приносимые в бассейн карбонатные растворы создавали щелочную среду. Последнее особенно развито в зонах с затрудненным водообменом, широкое распространение которых в Тавдинском море зафиксировано по палеонтологическим данным (явление мас- сового замора фауны). Щелочная среда всячески благоприятствует сохранению смектитовых минералов и, одновременно, деструкции биоморфной структуры кремнескелетной флоры. Далее при диагенезе происходит раскристаллизация гелей и многообразные трансформации терригенных глинистых минералов в смешаннослойные смектит-слюдистые агрегаты, далее в смектиты, а после - через промежуточную стадию корренсита - в хлорит.

Формирование таких смешаннослойных масс, вероятно, обусловлено трансформацией обломочных минералов и первичного субстрата [19, 20]. Первое появление переходного минерала между смектитом и хлоритом корренсита наиболее типично для температур порядка $100{ }^{\circ} \mathrm{C}$ [21-23], что, по всей видимости, близко к максимальным величинам температур, имевшим место в процессе диагенеза погребения для этих пород. Диагностированные глинистые минералы генетически ассоциируют с различными комплексами пород - кислыми и основными, что говорит о существенной площади областей сноса с Урала в бассейн седиментации. Конфигурация кристаллитов каолинита говорит о высокой степени его выветрелости. 

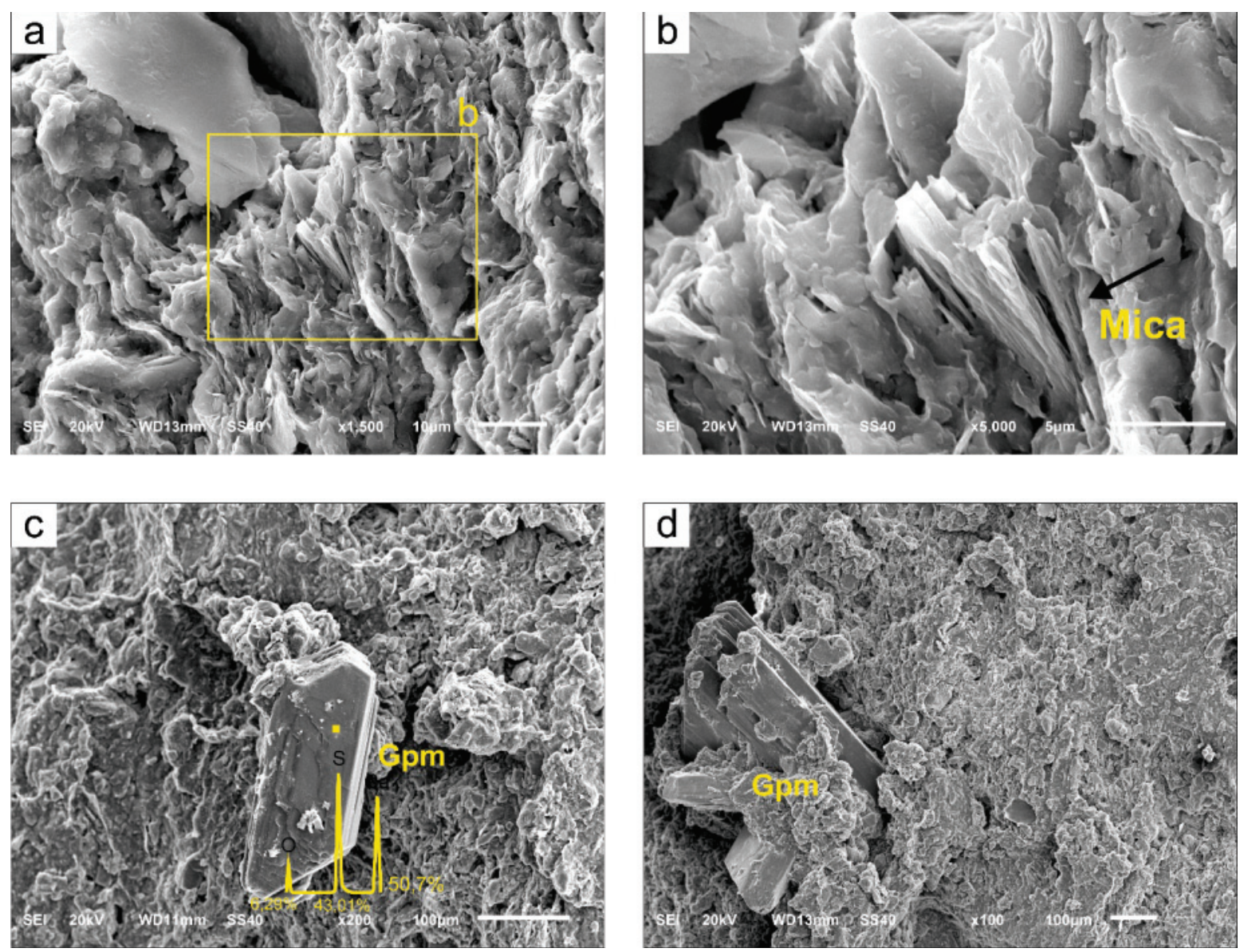

Рис. 7. Микроструктура и минеральные компоненты глин верхнетавдинской подсвиты: a, b) смешаннослойные массы на основе смектита; с) монокристалл гипса; d) «тройниковые» срастания гипса. Міса - слюда; Gpm - гипс

Fig. 7. Microstructure and mineral components of upper Tavda subformations clays: a, b) smectite-based mixed-layer masses; c) gypsum single crystal; d) «triple» accretions of gypsum. Mica - mica; Gpm - gypsum

Установленные распределения элементов индицирует существенные изменения в окислительно-восстановительных условиях морского бассейна на различных этапах его существования $[24,25]$. Нельзя исключать влияние гидротермальной деятельности в ходе процессов диагенеза.

С прикладной точки зрения, изученные горные породы - это глины, состоящие из смешаннослойных глинистых минералов и в которых монтмориллонит распространен, но не является основным компонентом. Кыштырлинские глины, будучи полиминеральными, не могут рассматриваться в качестве аналога бентонитов. По этой причине тезис о существенной схожести по минеральному составу Кыштырлинских глин с бентонитовыми глина- ми Татарстана не находит подтверждения. Здесь необходимо заметить, что Кыштырлинское месторождение относится к краевой части седиментационного бассейна: глинистые образования центральной фациальной зоны, вероятно, будут иметь существенные отличия.

Все чаще полиминеральные монтмориллонитсодержащие глины, дополнительно модифицированные продуктами пиролиза растительных наполнителей, используются как сырье для композиционных сорбционно-активных материалов $[26,27]$. Вероятно, такие новые направления переработки являются более реалистичными. Дополнительного исследования в таком случае требует вопрос содержания обменных катионов $\left(\mathrm{Ca}^{+}, \mathrm{Mg}^{++}\right.$, $\mathrm{Na}^{+}$и др.) в этих породах. 


\section{СПИСОК ЛИТЕРАТУРЫ}

1. Беспалова Ю.В., Масленников А.А., Малых А.Г. Результаты исследований глинистых отложений тавдинской свиты в пределах Кыштырлинского карьера и реконструкция палеоэкологических обстановок их образования // Известия высших учебных заведений. Нефть и газ. - 2017. - № 4. - С. 20-26.

2. Трубин Я.С. Ископаемые остатки костистых рыб семейства Scombridae из Тавдинской свиты юга Тюменской области // Проблемы геологии и освоения недр: Труды XXI Международного симпозиума имени академика М.А. Усова студентов и молодых учёных, посвященного 130-летию со дня рождения профессора М.И. Кучина. - Томск Изд-во Томского политехнического университета, 2017. - С. 82-83.

3. Первые находки ихнофоссилий в отложениях тавдинской свиты (средний-верхний эоцен) на юго-западе Западной Сибири / И.И. Нестеров, Я.С. Трубин, П.В. Смирнов, П.А. Ян // Доклады Академии наук. - 2018. - T. 481. - № 2. - С. 862-865. URL: doi.org/10.1134/S1028334X18070164 (дата обращения 15.11.2018)

4. First report of Eocene gadiform fishes from the Trans-Urals (Sverdlovsk and Tyumen regions, Russia) / G. Marrama, G. Carnevale, P.V. Smirnov, Ya.S. Trubin, J. Kriwet // Journal of Paleontology. - 2019. - V. 93. - № 5. - P. 1001-1009. DOI: 10.1017/jpa.2019.15

5. 0 составе моллюсков тавдинской свиты эоцена Западной Сибири / С.В. Попов, Я.С. Трубин, П.В. Смирнов, В.В. Ордовский, И.А. Гончарова, О.В. Амитров // Палеонтологический журнал. - 2019. - № 1. - С. 24-33. URL: doi.org/10.1134/ S0031030119010076 (дата обращения 15.11.2018).

6. Trubin Y.S. Family Naticidae of the Tavda formation (Eocene, Western Siberia) // Ruthenica. - 2018. - V. 28. - № 1. C. $11-17$.

7. Шпуров И.В., Файбусович Я.Э., Рыльков В.А. Задачи и перспективы развития минерально-сырьевой базы, основы экономического развития юга Тюменской области // Наука и ТЭК. 2011 - № 1. - С. $10-16$.

8. Файбусович Я.Э. Ресурсная база твердых полезных ископаемых юга Тюменской области // Недропользование XXI ВЕК. 2015. - № 3. - С. 156-163.

9. Гатиятуллин Н.С., Казаков Э.Р., Либерман В.Б. Оценка состояния ресурсной базы твердых нерудных полезных ископаемых республики Татарстан // Георесурсы. - 2015. - Т. 63. № 4-2. - C. 52-56. URL: http://dx.doi.org/10.18599/ grs.63.4.26 (дата обращения 15.11.2018).

10. Сабитов А.А. Месторождения бентонитов Республики Татарстан: геология и генезис, направления использования сырья // Георесурсы. - 2015. - Т. 63. - № 4-1. - С. 38-43.

11. Ахметьев М.А., Запорожец Н.И. События палеогена в Центральной Евразии, их роль в развитии флоры и растительного покрова, смещении границ фитохорий и изменениях климата // Стратиграфия. Геологическая корреляция. - 2014. - Т. 22 . № 3. - C. 90-114. D0I: 10.7868/S0869592X14030028

12. Волкова В.С., Кузьмина О.Б., Кулькова И.А. Морской и континентальный палеоген и миоцен южной части Барабинского фациального района Западной Сибири (стратиграфия, микрофитофоссшии) // Стратиграфия. Геологическая корреляция. 2004, - T. 46. - № 1. - C. 60-71.

13. Новые данные по морскому палеогену юга Западно-Сибирской плиты. Статья 1 / М.А. Ахметьев, Г.Н. Александрова, В.Н. Беньямовский, Д.И. Витухин, З.И. Глезер, З.Н. Гнибиденко, В.Д. Дергачев, Ж.А. Доля, Н.И. Запорожец, Г.Е. Козлова, И.А. Кулькова, И.А. Николаева, М.Н. Овечкина, Э.П. Радионова, Н.И. Стрельникова // Стратиграфия. Геологическая корреляция. - 2004. - V. 12. - № 1. - С. 58-84.

14. Wedepohl K.H. The composition of the continental crust // Geochimica et Cosmochimica Acta. - 1995. - V. 59. - № 7. C. 1217-1232. DOI: 10.1016/0016-7037(95)00038-2
15. Summary of recommendations of nomenclature committees relevant to clay mineralogy: Report of the Association International pour l'Etude des Argiles (AIPEA) Nomenclature Committee for 2006 (Clays and Clay Minerals) / S. Guggenheim, J.M. Adams, D.C. Bain, F. Bergaya, M.F. Brigatti, V.A. Drits, M.L.L. Formoso, E. Galan, T. Kogure, H. Stanjek // Clays and Clay Minerals. 2007. - V. 55. - № 6. - C. 761-772. DOI: $10.1346 /$ CCMN.2006.0540610

16. Lazaro B.B. Halloysite and kaolinite: two clay minerals with geological and technological importance // Revistas de la Real Academia de Ciencias de Zaragoza. - 2015. - V. 70. - P. 7-38.

17. Kadir S., Akbulut A. Mineralogy, geochemistry and genesis of the Tasoluk kaolinite deposits in pre-Early Cambrian metamorphites and Neogene volcanites of Afyonkarahisar, Turkey // Clay Minerals. - 2009. - 44. - C. 89-112. URL: doi.org/10.1180/claymin.2009.044.1.89 (дата обращения 15.11.2018).

18. Smectite-, silica- and zeolites-bearing raw materials (Hliník nad Hronom bentonite, Slovakia) - a new approach using integrated petrographic and mineralogical studies / K. Gorniak, T. Szydłak, A. Gaweł, A. Klimek, A. Tomczyk, J. Motyka, K. Bahranowski // Applied Clay Science. - 2017. - V. - 141. - C. 180-191. DOI: 10.1016/j.clay.2017.02.032

19. Net L.I., Alonso S.M., Limarino C.0. Source rock and environmental control on clay mineral associations, Lower Section of $\mathrm{Pa}$ ganzo Group (Carboniferous), Northwest Argentina // Sedimentary Geology. - 2002 - V. 152. - № 3. - C. 183-199.

20. Clay mineralogy of the middle Mingshui Formation (upper Campanian to lower Maastrichtian) from the SKIn borehole in the Songliao Basin, NE China: Implications for palaeoclimate and provenance / Y. Gao, C. Wang, Z. Liu, B. Zhao, X. Zhang // Palaeogeography, Palaeoclimatology, Palaeoecology. - 2013. V. 385 . - C. $162-170$. URL: doi.org/10.1016/j.palaе 2012.10 .038 (дата обращения 15.11.2018).

21. Inoue A., Utada M. Smectite to chlorite transformation in thermally metamorphosed volcanoclastic rocks in the Kamikita area, northern Honshu, Japan // American Mineralogist. - 1991. V. 76. - C. 628-640.

22. Hiller S. Origin, diagenesis, and mineralogy of chlorite minerals in Devonian lacustrine mudrocks, Orcadian basin, Scotland // Clays and Clay Minerals. - 1993. - V. 41. - № 2. - P. 240-259.

23. Occurrence of $\mathrm{Fe}-\mathrm{Mg}$-rich smectites and corrensite in the Morrón de Mateo bentonite deposit (Cabo de Gata region, Spain): a natural analogue of the bentonite barrier in a radwaste repository / M. Pelayo, E. García-Romero, E. García-Romero, M.A. Labajo, L. Pérez del Villar // Applied Geochemistry, - 2011. - V. 26. № 7. - C. 1153-1168.

24. Trace metals as paleoredox and paleoproductivity proxies: an update / N. Tribovillard, T.J. Algeo, T. Lyons, A. Riboulle // Chemical Geology. - 2006. - V. 232. - № 1-2. - C. 12-32.

25. Géologie de la matière organique / ed. by F. de Baudin, N. Tribovillard, J. Trichet. - Paris: EDP Sciences Géosphères, 2017. $-310 \mathrm{p}$.

26. New energy-efficient method for producing nanostructured composite sorbent based on plant bypass (coffee husks) and montmorillonite clay from province of Lam Dong / A.I. Vezentsev, H.C. Nguen, P.V. Sokolovskiy, V.D. Buhanov // International Journal of Pharmacy and Technology. - 2016. - V. 8. - № 2. C. $14236-14243$.

27. Pairing micropollutants and clay-composite sorbents for efficient water treatment: filtration and modeling at a pilot scale / F. Lelario, I Gardi, Y. Mishael, N. Dolev, T. Undabeytia, S., Nir, L. Scrano, A. Sabino, S.A. Bufo // Applied Clay Science. - 2017. V. 137. - C. 225-232. URL: doi.org/10.1016/j.clay.2016.12.029 (дата обращения 15.11.2018). 


\section{Информация об авторах}

Слирнов П.В., кандидат геолого-минералогических наук, научный сотрудник Центра перспективных исследований и разработок Тюменского индустриального университета; научный сотрудник Института экологической и сельскохозяйственной биологии Тюменского государственного университета.

Дерягина О.И., заведующая лабораторией литолого-петрофизических исследований горных пород ООО «Западно-Сибирский геологический центр».

Новоселов $A . A$., аспирант кафедры физической географии и экологии Института наук о Земле Тюменского государственного университета; младший научный сотрудник Центра перспективных исследований и разработок Тюменского индустриального университета.

Tpyбин Я.С., специалист НОЦ «Геология нефти и газа» Тюменского индустриального университета.

Баталин $\boldsymbol{\Gamma} . \boldsymbol{A}$., научный сотрудник Казанского федерального университета.

Гареев Б.И., научный сотрудник Казанского федерального университета.

Плюснин A.B., аспирант кафедры региональной геологии Пермского государственного национального исследовательского университета. 


\title{
EOCENE TAVDA FORMATION CLAYS: LITHOGEOCHEMICAL AND SEDIMENTOLOGICAL ASPECTS (KYSHTYRLINSKOE DEPOSIT, WEST SIBERIA)
}

Pavel V. Smirnovi,

geolog.08@mail.ru

Oksana I. Deryagina ${ }^{3}$,

deriaginaoksanazsgc@yandex.ru

Andrey A. Novoselov,

mr.andreygeo@mail.ru

\section{Yaroslav S. Trubin',}

mr.andreygeo@mail.ru

\section{Georgii A. Batalin ${ }^{4}$}

g@batalin.com

\section{Bulat I. Gareev ${ }^{4}$,}

bulat@gareev.net

\author{
Alexey V. Plyusnin ${ }^{5}$, \\ geolog0112@mail.ru \\ 1 Tyumen Industrial University, \\ 38, Volodarsky street, Tyumen, 625000, Russia. \\ 2 University of Tyumen, \\ 6, Volodarsky street, Tyumen, 625003 Russia. \\ ${ }^{3}$ West Siberian Geological Center, \\ 11/2, Surgutskaya street, Tyumen, 625002, Russia. \\ ${ }^{4}$ Kazan Federal University, \\ 4/5, Kremlevskaya street, Kazan, 420008, Russia. \\ ${ }^{5}$ Perm State Technical University, \\ 15, Bukireva street, Perm, 614990, Russia.
}

\begin{abstract}
Relevance. Mineral composition of Tavda formation clays has been studied repeatedly. The results obtained in geological reports and few published works are often poorly correlated with each other. Such a contradiction is caused by sampling for technological tests from different areas, which belong to two subformations, which have a number of differences. The age, stratigraphic position, and chemical and mineralogical features of the Tavda formation remain debatable and relevant issues, which requires additional study. A detailed study of the lithology of Tavda formation clays assumes importance in relation to the plans to expand the resource base and the need to reprofile the part of manufacturing capacity for the production of new commercial products.

The main aim of the research is precise studies of material composition of the bulk samples from the lower and upper subformations of the Tavda formation

Methods: field studies, $X$-ray diffraction, $X$-ray fluorescence analysis, determination of refractoriness, inductively coupled plasma mass spectrometry, scanning electron microscopy, lithological and petrographic analysis in thin sections.

Results. The paper presents the results of the studies of chemical and mineralogical compositions, features of lithology and microstructure of clay rocks from the Kyshtyrlinskiy site (Tyumen region). Clay rocks have a certain variability of mineral composition: but the clay mica mixed-layer-smectite matrix is constant. In the lower part, the clay rock mass is composed mainly of mica and mixed-layer illitesmectite formations. The upper subformation clays are more closely related to the kaolin-mica-montmorillonite type with admixtures of pyrite, silica, sulfates, carbonates and organic substances. The formation of such mixed-layer masses is probably due to degradation of detrital minerals and the primary clay substrate. The established distribution of rare earth elements indicates significant changes in the redox conditions of the marine basin at various stages of its existence. The studied clay is considered as bentonite-like.
\end{abstract}

Key words:

Clay, clay minerals, Tavda formation, Eocene, non-metallic minerals, Western Siberia. 


\section{REFERENCES}

1. Bespalova Yu.V., Maslennikov A.A., Malykh A.G. Rezultaty issledovaniy glinistykh otlozheniy tavdinskoy svity v predelakh Kyshtyrlinskogo karera i rekonstruktsiya paleoekologicheskikh obstanovok ikh obrazovaniya [The results of studies of clay deposits of the Tavda formation within the Kyshtyrlinsliy quarry and reconstruction of the paleoecological settings of their formation]. Izvestiya vysshikh uchebnykh zavedeniy. Neft i gaz, 2017, no. 4, pp. 20-26.

2. Trubin Ya.S. Iskopaemye ostatki kostistykh ryb semeystva Scombridae iz Tavdinskoy svity yuga Tyumenskoy oblasti [Fossil remains of bony fish of the family Scombridae from the Tavdinskaya suite of the south of the Tyumen region]. Problemy geologii i osvoeniya nedr. Trudy XXI Mezhdunarodnogo simpoziuma imeni akademika M.A. Usova studentov $i$ molodykh uchenykh, posvyashchennogo 130-letiyu so dnya rozhdeniya professora M.I. Kuchina [Problems of Geology and Subsurface Development: Proc. of the 20th International Scientific Symposium of students, Postgraduates and young Scientists devoted to the 130th Since the birth of Professor M.I. Kuchin]. Tomsk, Tomsk Polytechnic University Publ. House, 2017. pp. 82-83.

3. Nesterov I.I., Trubin Y.S., Smirnov P.V., Yan P.A. First findings of trace fossils from the Tavda formation (Middle-Upper Eocene) in the southwestern part of Western Siberia. Doklady Earth Sciences, 2018, vol. 481. pp. 62-65. Available at: doi.org/ 10.1134/S1028334X18070164 (accessed 15 November 2018).

4. Marrama G., Carnevale G., Smirnov P.V., Trubin Ya.S., Kriwet J. First report of Eocene gadiform fishes from the Trans-Urals (Sverdlovsk and Tyumen regions, Russia). Journal of Paleontology, 2019, vol. 93, no. 5, pp. 1001-1009. DOI: 10.1017/jpa.2019.15

5. Popov S.V., Trubin Y.S., Smirnov, P.V., Ordovsly V.V., Goncharova I.A., Amitrov 0.V. On the taxonomic composition of mollusks from the Tavda formation of Western Siberia. Paleontological Journal, 2019, vol. 53, no. 1, pp. 20-29. In Rus. Available at: doi.org/10.1134/S0031030119010076 (accessed 15 November 2018).

6. Trubin Y.S. Family Naticidae of the Tavda formation (Eocene, Western Siberia). Ruthenica, 2018, vol. 28, no. 1, pp. 11-17.

7. Shpurov I.V., Faybusovich Ya.E., Rylkov V.A. Zadachi i perspektivy razvitiya mineralno-syrevoy bazy, osnovy ekonomicheskogo razvitiya yuga Tyumenskoy oblasti [Objectives and prospects of development of the mineral resource base, the basis of economic development of the south of the Tyumen region]. Nauka $i$ TEK, 2011, no. 1, pp. 10-16.

8. Faybusovich Ya.E. Resource base of solid minerals in the south of the Tyumen region. Nedropolzovanie XXI VEK, 2015, no. 3, pp. 156-163. In Rus.

9. Gatiyatullin N.S., Kazakov E.R., Liberman V.B. Otsenka sostoyaniya resursnoy bazy tverdykh nerudnykh poleznykh iskopaemykh respubliki Tatarstan [Assessment of the resource base of solid non-metallic minerals of the Republic of Tatarstan]. Georesur sy, 2015, vol. 63, no. 4-2, pp. 52-56. Available at: dx.doi.org/10.18599/grs.63.4.26 (accessed 15 November 2018).

10. Sabitov A.A. Deposits of bentonites of the Republic of Tatarstan: geology and genesis, uses of raw materials. Georesursy, 2015, vol. 63 , no. 4-1, pp. 38-43. In Rus. Available at: http://dx.doi. org/10.18599/grs.63.4.6 (accessed 15 November 2018).

11. Akhmetev M. A., Zaporozhets N. I. Paleogene Events in Central Eurasia: Their Role in the Flora and Vegetation Cover Evolution, Migration of Phytochore Boundaries, and Climate Changes. Stratigraphy and Geological Correlation, 2014, vol. 22, no. 3, pp. 312-335. Available at: doi.org/10.1134/S0869593814030022 (accessed 15 November 2018).

12. Volkova V.S., Kuzmina O.B., Kulkova I.A. Marine and continental Paleogene and Miocene of southern Baraba facies region of West Siberia: Stratigraphy and microphytofossils. Russia Geology and Geophysics, 2005, vol. 46, no. 1, pp. 60-71. In Rus.
13. Akhmetev M.A., Aleksandrova G.N., Beniamovskii V.N., Vitukhin D.I., Glezer Z.I., Gnibidenko Z.N., Dergachev V.D., Dolya Zh.A., Zaporozhets N.I., Kozlova G.E., Kulkova I.A., NikolaevaI.A., Ovechkina M.N., Radionova E.P., Strelnikova N.I. New data on the marine Paleogene of the southwestern Siberian plate. P. 1. Stratigraphy and Geological Correlation, 2004, vol. 12 , no. 1, pp. 58-84. In Rus.

14. Wedepohl K.H. The composition of the continental crust. Geochimica et Cosmochimica Acta, 1995, vol. 59, no. 7, pp. 1217-1232. DOI: 10.1016/0016-7037(95)00038-2

15. Guggenheim S., Adams J.M., Bain D.C., Bergaya F., Brigatti M.F., Drits V.A., Formoso M.L.L., Galan E., Kogure T., Stanjek H. Summary of recommendations of nomenclature committees relevant to clay mineralogy: report of the Association International pour l'Etude des Argiles (AIPEA) Nomenclature Committee for 2006 (Clays and Clay Minerals). Clays and Clay Minerals, 2007, vol. 55, no. 6, pp. 761-772. D0I: 10.1346/CCMN.2006.0540610

16. Lazaro B.B. Halloysite and kaolinite: two clay minerals with geological and technological importance. Revistas de la Real Academia de Ciencias de Zaragoza, 2015, vol. 70, pp. 7-38.

17. Kadir S., Akbulut A. Mineralogy, geochemistry and genesis of the Tasoluk kaolinite deposits in pre-Early Cambrian metamorphites and Neogene volcanites of Afyonkarahisar, Turkey. Clay Minerals, 2009, vol. 44, pp. 89-112. Available at: doi.org/10.1180/claymin.2009.044.1.89 (accessed 15 November 2018).

18. Gorniak K., Szydłak T., Gaweł A., Klimek A., Tomczyk A., Motyka J., Bahranowski K. Smectite-, silica- and zeolites-bearing rawmaterials (Hliník nad Hronom bentonite, Slovakia) - a new approach using integrated petrographic and mineralogical studies. Applied Clay Science, 2017, vol. 141, pp. 180-191. DOI: 10.1016/j.clay.2017.02.032

19. Net L.I., Alonso S.M., Limarino C.0. Source rock and environmental control on clay mineral associations, Lower Section of Paganzo Group (Carboniferous), Northwest Argentina. Sedimentary Geology, 2002, vol. 152, no. 3, pp. 183-199.

20. Gao Y., Wang C., Liu Z., Zhao B., Zhang X. Clay mineralogy of the middle Mingshui Formation (upper Campanian to lower Maastrichtian) from the SKIn borehole in the Songliao Basin, NE China: Implications for palaeoclimate and provenance. Palaeogeography, Palaeoclimatology, Palaeoecology, 2013, vol. 385, pp. 162-170. Available at: doi.org/10.1016/j.palae0.2012.10.038 (accessed 15 November 2018).

21. Inoue A., Utada M. Smectite to chlorite transformation in thermally metamorphosed volcanoclastic rocks in the Kamikita area, northern Honshu, Japan. American Mineralogist, 1991, vol. 76, pp. $628-640$.

22. Hiller S. Origin, diagenesis, and mineralogy of chlorite minerals in Devonian lacustrine mudrocks, Orcadian basin, Scotland. Clays and Clay Minerals, 1993, vol. 41, no. 2, pp. 240-259.

23. Pelayo M., García-Romero E., García-Romero E., Labajo M.A., Pérez del Villar L. Occurrence of Fe-Mg-rich smectites and corrensite in the Morrón de Mateo bentonite deposit (Cabo de Gata region, Spain): A natural analogue of the bentonite barrier in a radwaste repository. Applied Geochemistry, 2011, vol. 26, no. 7, pp. $1153-1168$.

24. Tribovillard N., Algeo Th.J., Lyons T., Riboulle A. Trace metals as paleoredox and paleoproductivity proxies: an update. Chemical Geology, 2006, vol. 232, no. 1-2, pp. 12-32.

25. Güologie de la matiure organique. Eds. F. de Baudin, N. Tribovillard, J. Trichet. Paris, EDP Sciences Géosphères, 2017. 310 p.

26. Vezentsev A.I., Nguen H.C., Sokolovskiy P.V., Buhanov V.D. New energy-efficient method for producing nanostructured composite sorbent based on plant bypass (coffee husks) and montmorillonite clay from province of Lam Dong. International Journal of Pharmacy and Technology, 2016, vol. 8, no. 2, pp. $14236-14243$. 
27. Lelario F., Gardi I, Mishael Y., Dolev N., Undabeytia T., Nir S., Scrano L., Sabino A., Bufo S.A. Pairing micropollutants and claycomposite sorbents for efficient water treatment: Filtration and modeling at a pilot scale. Applied Clay Science, 2017, vol. 137,

\section{Information about the authors}

Pavel V. Smirnov, Cand. Sc., scientific researcher, Center for Advanced Research and Development, Tyumen Industrial University; scientific researcher, Institute of Environmental and Agricultural Biology, University of Tyumen.

Oksana I. Deryagina, head of Laboratory of Lithophysical and Petrophysical Studies of Rocks, West Siberian Geological Center.

Andrey A. Novoselov, postgraduate, University of Tyumen; junior researcher, Center for Advanced Research and Development, Tyumen Industrial University.

Yaroslav S. Trubin, specialist of Research and Education Center, Tyumen Industrial University.

Georgii A. Batalin, scientific researcher, Kazan Federal University.

Bulat I. Gareev, scientific researcher, Kazan Federal University.

Alexey V.Plyusnin, postgraduate, Perm State National Research University. 